\title{
TOOTH SIZE DISCREPANCIES AND DENTAL ARCH WIDTH IN PATIENTS WITH PALATALLY AND LABIALLY IMPACTED MAXILLARY CANINES
}

\author{
Rūta Stanaitytè ${ }^{1}$, Dalia Smailiené2 ${ }^{2}$ Ignas Kaduševičius ${ }^{1}$ \\ ${ }^{1}$ Lithuanian University of Health Sciences, Medical Academy, Faculty of Odontology, \\ ${ }^{2}$ Department of Orthodontics, Medical Academy, Lithuanian University of Health Sciences
}

Key words: impacted canine, Bolton ratios, tooth size.

\section{Summary}

It has been reported that labial displacement of the upper permanent canine is most frequently associated with crowding and constriction of the dental arch, but palatally impacted canines have sufficient space to erupt and are associated with a reduction of teeth width.

Aim. To compare the Bolton ratios, individual tooth and dental arch widths in patients with unilateral palatally and labially impacted canines.

Methods. The study sample consisted of 75 patients with unilaterally impacted maxillary canines (palatal impaction group $\mathrm{n}=48$ (64\%), labial impaction group $n=27(36 \%))$. Teeth width, upper dental arch width and form analysis was performed on the pretreatment dental casts. Bolton's ratio was calculated.

Results. There were no differences in tooth widths between palatal and labial impaction groups, (except central incisors that were significantly smaller on the impaction side in both groups). No statistical relation between impacted tooth position on labio-palatal direction and meaning of the Bolton's ratio was found. $54.66 \%$ of patients had normal anterior Bolton's ratio and 53.33\%- normal overall Bolton's ratio. The distance between upper first molars and first premolars does not differ in both impaction groups. No statistical correlation was found between the upper dental arch form and impacted canine position in labio-palatal direction.

Conclusion. Central incisors were significantly smaller on the impaction side of the dental arch in both palatally and labially impaction groups. No differences in the Bolton ratios, dental arch form and transversal width in patients with unilateral palatally and labially canine impaction were found.

\section{Introduction}

Most canine eruption anomalies diverge from the normal eruptive site in either of two directions: palatal or labial. It has been reported that the prevalence of palatally impacted canines (PIC) is by an almost sixfold greater than labially impacted canines (LIC) [1]. Both genetic and local factors have been shown to be intimately associated with eruption disturbances of the maxillary canine [2].

According to the etiology and related occlusal features, PIC and LIC is considered to be different diagnoses. Most PIC cases are characterized as being nonextraction cases $[1,3]$, because the teeth of such patients appear smaller than average [4-7] and dental arches are broader than in other patients [8]. Whereas general opinion is that LIC is more commonly related to insufficient arch length and associated with crowding [9].

Tooth size and dental arch dimensions are determining factors in dental crowding. Besides tooth crowding could be conditioned not only by tooth size-dental arch size disproportion, bul also by inter-arch tooth size discrepancies, which are described as Bolton ratio. Bolton analysis is the widely used method for measuring tooth size discrepancies, especially in the anterior region of the dental arch, where relative tooth sizes control the amount of overbite, overjet, crowding and spacing. According to Proffit approximately $5 \%$ of the population has a significant tooth size discrepancy because of disproportion in size of the upper and lower teeth [10]. Anomalies in upper lateral incisors are the most common cause of such disproportion, but variation in premolar and other teeth also present. Al-Nimri et al. evaluating Bolton ratio in female patients concluded that patients with unilateral PIC do not have more inter-arch tooth size discrepancies than patients without PIC [11]. 
Our study aim was to compare the Bolton ratio individual tooth and dental arch widths in patients with unilateral PIC and LIC.

\section{Material and Methods}

The material consisted of the pre-treatment dental casts of 75 (59 female and 16 male) patients with unilateral impacted maxillary canine. The patients for this study were selected from the Orthodontic Clinic, Lithuanian University of Health Sciences according to the following criteria:

a) Non-syndromic patients with unilaterally impacted upper permanent canine (non-erupted after complete root development or if the contra-lateral tooth was erupted for at least 6 months with complete root formation [12],

b) No previous orthodontic treatment,

c) No teeth loss or agenesis that may affect the occlusion.

In $48(64 \%)$ of cases canine was impacted in palatal position, in $27(36 \%)$ in labial position.

Examination included:

- Tooth width analysis. The widths (greatest mesiodistal diameter from the anatomic mesial contact point to the anatomic distal contact point parallel to the incisal surfaces of the teeth) of all teeth were calculated and compared between impaction and non-impaction sides. The mesio-distal diameter of the impacted canine was measured on the casts taken at the end of ortohodontic treatment.

- Bolton's analysis. The proportionality of both dental arches was measured according to the Bolton analysis and compared Bolton's mean ratios: ratio for 12 teeth: $91.3 \pm 1.91( \pm 2 \mathrm{SD})$; and ratio for 6 teeth: $77.2 \pm 1.65( \pm 2 \mathrm{SD})$ [13-14].

- Dental arch width analysis. The arch width between upper first premolars measured with the calliper tips placed into the deepest portion of the central fossae of the upper first premolars at their junctions with the most lingual aspect of the buccal cusp. The arch width between upper first molars measured by placing the calliper tips into the deepest portion of the middline of the inter-cuspal fissures.

- The upper dental arch form was evaluated according to the upper dental arch model by overlying transparent sheet with dental arch form tamplate [15]:
a) Oval
b) Tapered
c) Square.

All dental cast measurements were made by the same examiner (RS) using sliding caliper (Dentaurum, Germany) to $0.1 \mathrm{~mm}$. Errors in measurement were analyzed by measuring randomly selected 20 dental casts for the second time by the same caliper in an interval of 10 days. Paired $\mathrm{t}$ test was done to the first and second measurement. No significant differences found, so concluded that the measurement was reliable.

Statistical analysis. The SPSS (version 17.0) computer program was used for the statistical analyses. The differences between the impaction and non-impaction upper dental arch sides were determined using a chi-square test and a Student's t-test. P values less than 0.05 were considered significant.

\section{Results}

Teeth width analysis. There were no differences in tooth widths between PIC and LIC groups; however central incisors were significantly smaller on the impaction side of the dental arch (Table 1).

\section{Bolton's analysis}

The average anterior Bolton's ratio for PIC group was 78.74 \pm 3.3 and for LIC group- 78.36 $\pm 3.3 \quad(p>0.05)$. The average overall Bolton's ratio for PIC group was $89.89 \pm 3.82$ and for LIC group- $90.64 \pm 3.82(\mathrm{p}>0.05)$. No statistical relation between impacted tooth position in the labio-palatal direction and meaning of the Bolton's ratio was found. All the data presented in Table 2.

Dental arch width analysis. No statistical relation was found between impacted tooth position in the labio-palatal direction and the distance between upper first premolars and first molars. All the data are present in Table 3.

Upper dental arch form analysis

Tapered upper dental arch form was found in 29 cases (60.4\%) in PIC and 19 cases (70.37\%) in LIC. Oval arch form was found in 15 cases $(31.3 \%)$ in PIC and 8 cases $(29.62 \%)$ in LIC. Square dental arch form was only in 4 cases $(8.3 \%)$ in PIC group. No statistical correlation was found between the upper dental arch form and impacted canine position in labio-palatal direction.

\section{Discussion}

The purpose of this study was to compare the individual tooth widths, Bolton ratios and dental arch widths in patients with unilateral PIC and LIC.

Results of our study showed no significant difference in the mesiodistal widths of the maxillary teeth between impaction and non-impaction sides, except central incisors that were statistically significantly smaller on the impaction side of the dental arch in both groups. Although lateral incisors were smaller on the impaction side in PIC group, this difference was not statistically significant.

Distal root surface of the maxillary lateral incisor is important in guiding the maxillary canine into the arch during 
Table 1. Comparison of the mesio-distal dimensions (in millimeters) of the maxillary tooth widths on the impaction and non-impaction sides.

\begin{tabular}{|c|c|c|c|c|c|c|c|c|c|c|c|}
\hline \multicolumn{6}{|c|}{ PIC group } & \multicolumn{6}{|c|}{ LIC group } \\
\hline Tooth & $\begin{array}{l}\text { Impaction/non- } \\
\text { impaction side }\end{array}$ & Mean & n & SD & p & Tooth & $\begin{array}{l}\text { Impaction/non- } \\
\text { impaction side }\end{array}$ & Mean & $\mathbf{n}$ & SD & p \\
\hline \multirow{2}{*}{$\begin{array}{c}\text { Second } \\
\text { premolar }\end{array}$} & Impaction & 7.16 & 48 & 0.54 & \multirow{2}{*}{$\mathrm{p}>0.05$} & \multirow{2}{*}{$\begin{array}{c}\text { Second } \\
\text { premolar }\end{array}$} & Impaction & 7.24 & 27 & 0.63 & \multirow[t]{2}{*}{$p>0.05$} \\
\hline & Non-impaction & 7.17 & 48 & 0.45 & & & Non-impaction & 7.11 & 27 & 0.52 & \\
\hline \multirow{2}{*}{$\begin{array}{c}\text { First } \\
\text { premolar }\end{array}$} & Impaction & 7.34 & 48 & 0.53 & \multirow[t]{2}{*}{$\mathrm{p}>0.05$} & \multirow{2}{*}{$\begin{array}{c}\text { First } \\
\text { premolar }\end{array}$} & Impaction side & 7.22 & 27 & 0.54 & \multirow[t]{2}{*}{$\mathrm{p}>0.05$} \\
\hline & Non-impaction & 7.26 & 48 & 0.59 & & & Non-impaction & 7.26 & 27 & 0.56 & \\
\hline \multirow[t]{2}{*}{ Canine } & Impaction & 8.20 & 48 & 0.62 & \multirow[t]{2}{*}{$\mathrm{p}>0.05$} & \multirow[t]{2}{*}{ Canine } & Impaction & 8.09 & 27 & 0.62 & \multirow[t]{2}{*}{$\mathrm{p}>0.05$} \\
\hline & Non-impaction & 8.15 & 48 & 0.89 & & & Non-impaction & 8.02 & 27 & 0.71 & \\
\hline \multirow{2}{*}{$\begin{array}{l}\text { Lateral } \\
\text { incisor }\end{array}$} & Impaction & 7.39 & 48 & 1.08 & \multirow[t]{2}{*}{$\mathrm{p}>0.05$} & \multirow{2}{*}{$\begin{array}{l}\text { Lateral } \\
\text { incisor }\end{array}$} & Impaction & 7.20 & 27 & 0.70 & \multirow[t]{2}{*}{$\mathrm{p}>0.05$} \\
\hline & Non-impaction & 7.53 & 48 & 0.79 & & & Non-impaction & 7.28 & 27 & 0.81 & \\
\hline \multirow{2}{*}{$\begin{array}{l}\text { Central } \\
\text { incisor }\end{array}$} & Impaction & 9.27 & 48 & 0.52 & \multirow[t]{2}{*}{ p $<0.05$} & \multirow{2}{*}{$\begin{array}{l}\text { Central } \\
\text { incisor }\end{array}$} & Impaction & 9.30 & 27 & 0.52 & \multirow[t]{2}{*}{$\mathrm{p}<0.05$} \\
\hline & Non-impaction & 9.08 & 48 & 0.55 & & & Non-impaction & 8.98 & 27 & 0.58 & \\
\hline
\end{tabular}

Table 2. Bolton's ratio for 12 and 6 teeth $( \pm 2 S D)$.

\begin{tabular}{|c|c|c|c|c|c|}
\hline \multirow{2}{*}{$\begin{array}{l}\text { Bolton's ratio for } \\
12 \text { teeth }\end{array}$} & \multicolumn{2}{|c|}{ The position of impacted canine } & \multirow{2}{*}{$\begin{array}{c}\text { Bolton's ratio for } \\
6 \text { teeth }\end{array}$} & \multicolumn{2}{|c|}{ The position of impacted canine } \\
\hline & PIC & LIC & & PIC & LIC \\
\hline$<87.48 \pm 3.82$ & $10(20.8 \%)$ & $4(14.8 \%)$ & $<73.9 \pm 3.3$ & $7(14.6 \%)$ & $3(11.1 \%)$ \\
\hline $91.3 \pm 3.82$ & $29(60.4 \%)$ & $17(63.0 \%)$ & $77.2 \pm 3.3$ & $26(54.2 \%)$ & $15(55.6 \%)$ \\
\hline$>95.12 \pm 3.82$ & $9(18.8 \%)$ & $6(22.22 \%)$ & $>80.5 \pm 3.3$ & $15(31.3 \%)$ & $9(33.3 \%)$ \\
\hline Total: & $48(100 \%)$ & $27(100 \%)$ & Total: & $48(100 \%)$ & $27(100 \%)$ \\
\hline
\end{tabular}

Table 3. Distances between upper first premolars and first molars depending on the impacted canine position $(\mathrm{p}>0.05)$.

\begin{tabular}{|c|c|c|}
\hline $\begin{array}{l}\text { Impacted } \\
\text { canine } \\
\text { position }\end{array}$ & $\begin{array}{c}\text { Distance between } \\
\text { premolars } \\
\text { mm (SD) }\end{array}$ & $\begin{array}{c}\text { Distance between } \\
\text { molars } \\
\text { mm (SD) }\end{array}$ \\
\hline PIC & $34.36 \mathrm{~mm}(2.94)$ & $44.38 \mathrm{~mm}(3.38)$ \\
\hline LIC & $34.83 \mathrm{~mm}(3.37)$ & $44.17 \mathrm{~mm}(5.03)$ \\
\hline
\end{tabular}

eruption [16], therefore when the lateral incisor is small or absent there is a predisposition to the canine impaction $[4,8]$. Smaller lateral incisor in cases of PIC was recorded in many studies $[4,6,17]$. Langberg and Peck have shown that not only upper lateral, but also central incisors are smaller in PIC cases than in controls [5]. However Becker et al. stated that although there is a trend to mesio-distal narrower teeth in PIC patients, this difference reached statistical significance only for maxillary first premolars and molars in males and for central and lateral incisors in females [7]. Anic-Milosevic et al. stated that the only difference is a buco-lingual dimension for the central and lateral incisors which are significantly smaller on the impaction side of the dental arch in females [17]. Al-Nimri et al. and Brenchley and Oliver $[8,18]$ found no evidence to support the view that PIC is associated with diminutive maxillary teeth.

We found no relation between tooth widths and impacted tooth position in the labio-palatal direction. Only lateral incisors were smaller on the impaction side in PIC group, though this difference was not statistically significant. This is in disagreement with results of other studies. Artmann et $a l$. found that the widths of the lateral incisors in cases with LIC were on average $0.65 \mathrm{~mm}$ broader than in cases with PIC [19]. Chaushu et al. noted that LIC is associated with larger dimensions of the maxillary incisors than PIC $[2,20]$. In females it is due to larger-than-normal teeth in the LIC group and normally-sized teeth in the PIC group, whereas in the males-due to the normally-sized teeth in LIC group and the smaller-than normal teeth in PIC group.

No statistical relation between impacted tooth position in the labio-palatal direction and meaning of the Bolton's ratio was found. Al-Nimri et al. and Al-Khateeba et al. also did not find significant differences with regard to Bolton ratios between PIC patients and control group [6,11]. Bolton suggested that a ratio greater than 1SD from his reported mean values indicates a diagnostic consideration [14]. Other authors suggested that values inside 2SD of the Bolton's mean ratio have been clinically accepted for de- 
termining tooth size discrepancy [21]. The prevalence of Bolton's tooth-size discrepancies in the general populiation has been quoted as being $5 \%(6)$. However, many scientists showed completely different results, where approximately $22-28 \%$ of subjects have a significant deviation from Bolton's anterior ratio mean [22-23]. In the present study it was established that patients with impacted canines have even bigger deviation from the standart Bolton's ratio: only $54.66 \%$ of all patients had normal anterior Bolton's ratio. Overall Bolton's ratio was in normal limits in $53.33 \%$ of cases.

The distance between upper first molars and first premolars does not differ in both PIC and LIC groups. We did not find studies where the maxillary transverse arch width between PIC and LIC patients could be comparing. In many studies maxillary transverse arch width in patients with PIC or LIC comparing with the arch width in controls. Regarding PIC, results of researches are conflicting. Some authors confirm that where is no deficiency in either anterior or posterior maxillary transverse arch width in patients with PIC [17,24]. Stellzig et al. found arch length sufficiency in $82 \%$ of subjects with a PIC [25]. Al-Nimri et al. found that the upper arch is even significantly broader in patients with PIC than in other patients [8]. Though Al-Khateeba et $a l$. studying scaned dental casts concluded the total maxillary width in the PIC patients exhibit smaller dimensions than in the controls [6]. McConnell concluded that subjects with PIC demonstrate profound transverse maxillary deficiency located in the anterior portion of the dental arch [26]. Saiar et al. stated that the maxillary inter-canine alveolar arch width is not a good predictor to determine the anomaly of canine impaction [27].

While general opinion is that LIC is related to the constriction of the dental arch, Kafle et al., in acordance to our results, found any statistical difference between interpremolar and inter-molar arch width in LIC patients and control group [28]. Mucedero et al. shows that LIC subjects have reduced maxillary inter-canine width, however no significant differences were assessed for the comparisons of maxillary inter-molar width on the LIC group when compared with the control group [9]. Larsen concluded that in patients with ectopic (palatal/labial) maxillary canines the maxillary complex is shorter sagittally as well as vertically, while it is wider transversally [29].

Another feature related to maxillary transverse arch width is the upper dental arch form. No statistical correlation was found between the upper dental arch form and impacted canine position in labio-palatal direction. In the study by McConnell et al. also no significant difference in the arch form between the canine impaction group and non- impacted subjects was found [26]. Comparing upper dental arch forms we found that $\sim 60 \%$ of patients with PIC and $\sim 70 \%$ of patients with LIC impaction had tappered dental arch form. Olmez and Dogan [30] evaluating the dental arch forms on the non-impaction patients concluded that the most frequent dental arch form is tapered (62.5\%) followed by the ovoid (27.3\%) and the square one (10.2\%). The present study results (tapered form $65.38 \%$, ovoid- $30.46 \%$ and square-4.15\%) matched with Olmez and Dogan data. Similarly, Oliver et al. in his study found that both Caucasian and oriental patients groups have a higher incidence of tapered dental arch forms (4). It is believed that dental arch form is more determined by ethnical groups, rather than individual local factors: the most usual dental arch form in Caucasian patients is tapered, in Japanese-square [15].

Summarysing the results of our study, no differences in the Bolton ratios, dental arch widths and forms in patients with unilateral PIC and LIC were found. It is possible to simulate that canine impaction probably is not determine by a single factor, but is affected by several factors influence. Differences in the incidence of dental crowding in PIC and LIC patients does not depend on the teeth or dental arch widths. This is more likely to be concerned with other features of malocclusion. PIC is frequently related to Class II-2 malocclusion [8,16,31,34]. Bishara, Leifert and Jonas demonstrated that the prevalence of Class II-2 malocclusion and deep overbite in patients with impacted canines is higher than in the general population [33,34]. Ludicke et al. [16] found that patients with symptoms of Class II-2 malocclusion should be regarded as a risk group for canine impaction. Whereas LIC did not demonstrate significant associations with any specific craniofacial pattern in the sagittal plane [9] or is more often related to Class I and Class III malocclusion [28]. Other studies showed that LIC is significantly associated with hyperdivergent vertical skeletal relationships [9].

\section{Conclusion}

1. Central incisors were significantly smaller on the impaction side of the dental arch in both palatally and labially impaction groups.

2. No differences in the Bolton ratios, dental arch form and width in patients with unilateral PIC and LIC were found.

The authors state no conflict of interest

\section{References:}

1. Peck S, Peck L, Kataja M. The palatally displaced canine as a 
dental anomaly of genetic origin. Angle Orthod 1994;64:249-56.

2. Chaushu S, Sharabi S and Becker A. Tooth size in dentitions with buccal canine ectopia. Eur J Orthod 2003;25:485-91.

3. Jacoby H. The etiology of maxillary canine impaction. Am J Orthod 1983;84:125-32.

4. Oliver RG, Mannion JE, Robinson JM. Morphology of the maxillary lateral incisor in cases of unilateral impaction of the maxillary canine. Br Dent J 1989;19:9-16.

5. Langberg BJ, Peck S. Tooth-size reduction associated with occurrence of palatal displacement of canines. Angle Orthod 2000;70:126-28.

6. Al-Khateeba S, Alhaijab ESA, Rwaitec A, Burqand BA. Dental arch parameters of the displacement and nondisplacement sides in subjects with unilateral palatal canine ectopia. Angle Orthod.2012.Ahead of print.

7. Becker A, Sharabi S, Chaushu S. Maxillary tooth size variation in dentitions with palatal canine displacement. Eur J Orthod 2002;24:313-18.

8. Al-Nimri K, Gharaibeh T. Space conditions and dental and occlusal features in patients with palatally impacted maxillary canines:an aetiological study. Eur J Orthod 2005;27:461-5.

9. Mucedero M, Ricchiuti RM, Cozza P, Baccetti. Prevalence rate and dentoskeletal features associated with buccally displaced maxillary canines. Eur J Orthod 2011.Ahead of print.

10. Proffit WR. Contemporary Orthodontics, 3rd ed. St Louis:Mosby, 2000:165-70.

11. Al-Nimri K, Adwan I, Gharaibeh T, Hazza'a. Tooth size discrepancies in female patients with palatally impacted canines. Aust Orthod J 2008;24:129-33.

12. Lindauer S, Rubenstein L, Hang W, Andersen W, Isaacson R. Canine impaction identified early with panoramic radiographs. J Am Dent Assoc 1992;123:91-7.

13. Othman SA, Harradine NWT. Tooth-size Discrepancy and Bolton's Ratios: a literature review. J Orthod 2006;33:45-51.

14. Wayne A. Bolton. The clinical application of a tooth-size analysis. Am J Orthod 1962;48:505-29.

15. McLaughlin RP, Bennett JC, Trevisi HJ. Systemized orthodontic treatment mechanics. Mosby 2001:73-7.

16. Lüdicke G, Harzer W, Tausche E. Incisor Inclination-Risk Factor for Palatally-impacted Canines. J Orofac Orthop 2008;69:357-64.

17. Anic-Milosevic S, Varga S, Mestrovic S, Lapter-Varga M and Slaj M. Dental and occlusal features in patients with palatally displaced maxillary canines. Eur J Orthod 2009;31:367-73.

18. Brenchley Z, Oliver RG. Morphology of anterior teeth associated with displaced canines. Br Dent J 1997;24:41-5.

19. Artmann L, Larsen HJ, Sørensen HB, Christensen IJ, Kjaer I. Differences between dentitions with palatally and labially located maxillary canines observed in incisor width, dental morphology and space conditions. Eur J Paediatr Dent 2010;11:82-6.

20. Chaushu S, Bongart M, Aksoy A, Ben-Bassat Y, Becker A. Buc- cal Ectopia of Maxillary Canines in the Absence of Crowding. Am J Orthod Dentofac Orthop 2009;136:218-23.

21. Freeman JE, Maskeroni AJ, and Lorton L. Frequency of Bolton tooth-size discrepancies among orthodontic patients. Am J Orthod Dentofacial Orthop 1996;110:24-7.

22. Santoro M, Ayoub ME, Pardi VA, Cangialosi TJ. Mesiodistal crown dimensions and tooth size discrepancy of the permanent dentition of Dominican Americans. Angle Orthod 2000;70:303-7.

23. Araujo E, Souki M. Bolton anterior tooth size discrepancies among different malocclusion groups. Angle Orthod 2003;73:307-13.

24. Langberg BJ, Peck S. Adequacy of maxillary dental arch width in patients with palatally displaced canines. Am J Orthod Dentofacial Orthop 2000;118:220-3.

25. Stellzig A, Basdra EK, Komposch G. The etiology of canine tooth impaction-a space analysis. Eur J Orthod 1994;55:97-103.

26. McConnell TL, Hoffman DL, Forbes DP, Janzen EK, Weintraub NH. Maxillary canine impaction in patients with transverse maxillary deficiency. J Dent Child 1996;3:190-95.

27. Saiar M, Rebellato J, Sheatsb R. Palatal displacement of canines and maxillary skeletal width. Am J Orthod Dentofacial Orthop 2006;129:511-19.

28. Kafle D, Xia CS. The association of buccally impacted maxillary canine with other teeth anomalies and transalveolar maxillary arch width. Journal of Nepal Dental Association 2010;11:15-9.

29. Larsen HJ, Sørensen HB, Artmann L, Christensen IJ, Kjær I. Sagittal, vertical and transversal dimensions of the maxillary complex in patients with ectopic maxillary canines. Orthod Craniofac Res 2010;13:34-9.

30. Olmez S, Dogan S. Comparison of the arch forms and dimensions in various malocclusions of the Turkish population. Open Journal of Stomatology 2011;4:158-64.

31. Lima Filho RM, Bolognese AM. Treatment of a unilateral Class II-division 2 malocclusion with a palatally impacted canine. J Clin Orthod 2003;37:479-83.

32. Basdra EK, Kiokpasoglou M\&A Stellzig. The Class II-Division 2 craniofacial type is associated with numerous congenital tooth anomalies. Eur. J. Orthod 2000;22:529-35.

33. Leifert S, Jonas IE. Dental anomalies as a micro symptom of palatal canine displacement. J Orofac Orthop 2003;64:108-20.

34. Samir E. Bishara. Impacted maxillary canines: A review. Am J Orthod Dentofacial Orthop 1992;101:159-71.

\section{DANTŲ DYDŽIO IR DANTU LANKO PLOČIO SKIRTUMAI ESANT GOMURINEI IR LŪPINEI VIRŠUTINIO ŽANDIKAULIO NUOLATINIO ILTINIO DANTIES RETENCIJAI}

R. Stanaitytė, D. Smailienė, I. Kaduševičius

Raktažodžiai: retinuotas iltinis dantis, Boltono indeksas, dantų vainiko plotis. 
Santrauka

Manoma, kad viršutinio nuolatinio iltinio danties retencija lūpinèje padètyje yra susijusi su dantų lanko susiaurèjimu ir dantų susigrūdimu, o gomuryje retinuotas iltinis dantis dažniausiai susijęs su pakankama vieta jam išdygti ir dantų dydžio sumažèjimu.

Tikslas. Palyginti dantų bei dantų lankų pločius ir Boltono santykị pacientams su vienpuse lūpine arba gomurine nuolatinio iltinio danties retencija.

Tyrimo medžiaga ir metodai. Tyrimo imtị sudarè 75 pacientai su vienpuse viršutinio žandikaulio nuolatinio iltinio danties retencija (gomurinès retencijos grupé $\mathrm{n}=48(64 \%)$, lūpinès retencijos grupe $\mathrm{n}=27(36 \%)$. Atskirų dantų mediodistalinis plotis, viršutinio dantu lanko transversalinis plotis tarp pirmųų prieškrūminių ir krūminių dantų ir forma matuoti pagal gipsinius dantų lankų modelius, apskaičiuotas Boltono indeksas.

Rezultatai. Centriniai kandžiai buvo mažesni abiejų grupių retencijos pusèse. Nepastebèta statistiškai reikšmingo skirtumo tarp kitų dantų pločių esant lūpinei arba gomurinei iltinio danties retencijai. Taip pat nebuvo rasta jokio statistinio ryšio tarp retinuoto iltinio danties padèties lūpine -gomurine kryptimi ir Boltono reikšmès. Priekinių dantų Boltono indekso matavimas atitiko normą $54,66 \%$ atvejų, visų dantų Boltono indekso matavimas - 53,33\% atvejų. Atstumas tarp viršutinių pirmųų krūminių dantų ir pirmuju prieškrūminių dantų nesiskyrè abiejose grupèse. Nerasta statistinio skirtumo tarp viršutinio dantu lanko formos ir retinuoto iltinio danties padèties lūpine - gomurine kryptimi. 65,39\% pacientų nustatyta smailejanti dantų lanko forma.

Išvados. Abiejose grupése (lūpinèje ir gomurinejje) dantų lanko retencijos pusèje centriniai kandžiai buvo statistiškai mažesni. Nerasta ryšio tarp vienpusès lūpinès arba gomurinės iltinio danties retencijos ir Boltono indekso reikšmès, dantų lanko formos ir transversalinio dantų lanko pločio.

Adresas susirašinèti: rutastanaityte@gmail.com

Gauta 2014-02-15 